\title{
Analysis of the logistics services of ASEAN member countries
}

\author{
Yajie Huang \\ International Business School \\ Yunnan University of Finance and Economics \\ Kunming, China \\ 534633894@qq.com
}

\author{
Ning Yan* \\ International Business School \\ Yunnan University of Finance and Economics \\ Kunming, China \\ Ningyan68@126.com
}

\begin{abstract}
Chinese direct investment in ASEAN reached $\$ 14.604$ billion in 2016. The actual amount of direct investment by ASEAN in China presented a rising trend. According to the data from APEC Policy Support Unit (2016), as of the end of 2016, the total of two-way investment between China and ASEAN was more than $\$ 130$ billion, of which ASEAN Investment in China was more than $\$ 90$ billion. Therefore, evaluating the current situation of logistics service in ASEAN countries and the problems of logistics services in China is helpful to further develop the policy initiatives of ASEAN Economic Community.
\end{abstract}

Keywords-Southeast Asia; Southeast Asian Nations; trade; logistics services; trade barriers

\section{INTRODUCTION}

According to the CIES (2006), the most important barrier to services is the set of regulations that operates behind the border, which both impacts on foreign suppliers and local firms. Ben Shepherd, John S. Wilson, (2009) notes that Logistics services have an important impression on the import and export of a country. Jittichai and Wiracha (2014) say that there are some limiting factors in Port Development. According to the Li Xuan, (2016), the direction of modern logistics service is developing.

The economic and trade exchanges between China and ASEAN have become gradually active since 1990s. With the establishment of China ASEAN Free Trade Area in 2010, ASEANS Secretariat (2015-2016), bilateral investment has achieved a rapid development. With the strengthening of investment relationship between China and ASEAN, Logistics service level has begun to attract the attention of all countries.
Logistics service level plays an important role in transportation cost and time. In the process of trade facilitation, the analysis of logistics service quality is particularlytab

important. This paper analyzes the influences of the difference of logistics service in ASEAN countries, and through the analysis of the problems that encountered in the logistics between China and other countries, and puts forward some suggestions to solve the existing problems.

\section{LOGISTICS SERVICE DEFINITION}

According to the Sumeet and Mark (2011), logistics is the process of planning, operating, managing and controlling the flow and the storage of goods, services and related information from the origin to the consumer point

The core of freight logistics services includes cargo handling, warehousing and cargo transport agency, and supporting and auxiliary transport service. Firms which provide transport management services use their own equipment and transportation fleet to provide truckload, lessthan-truckload, air, or sea freight along with value-added logistics service, and therefore they are asset-intensive. Both transport management and supply chain consulting services are key services in the logistics sector.

\section{ASEAN COUNTRIES LOGISTICS SERVICE ANALYSIS}

Source: 2015-2016 Global Competitiveness Report.

Through the chart, ASEAN countries have different levels of logistics services:

TABLE I. ANALYSIS OF LOGISTICS SERVICES IN DIFFERENT COUNIRIES.

\begin{tabular}{|c|c|c|c|c|c|c|c|c|c|c|c|}
\hline \multicolumn{2}{|c|}{ Country } & \multirow{2}{*}{ 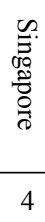 } & \multirow{2}{*}{ 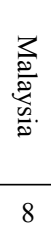 } & \multirow{2}{*}{$\begin{array}{l}\underset{\square}{\Xi} \\
\vec{\Xi} \\
\stackrel{\Xi}{\Xi} \\
15\end{array}$} & \multirow{2}{*}{ 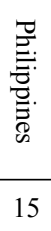 } & \multirow{2}{*}{ 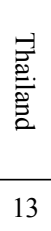 } & \multirow{2}{*}{ 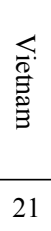 } & \multirow{2}{*}{ 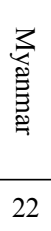 } & \multirow{2}{*}{ 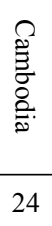 } & \multirow{2}{*}{$\begin{array}{l}\frac{5}{0} \\
26\end{array}$} & \multirow{2}{*}{ 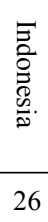 } \\
\hline \multirow{2}{*}{ Time (day) } & Imported & & & & & & & & & & \\
\hline & Exit & 6 & 11 & 19 & 15 & 14 & 21 & 20 & 22 & 17 & 23 \\
\hline \multirow{2}{*}{ Number of documents } & Imported & 3 & 4 & 5 & 7 & 5 & 8 & 8 & 9 & 8 & 10 \\
\hline & Exit & 3 & 4 & 5 & 6 & 5 & 5 & 8 & 8 & 4 & 10 \\
\hline
\end{tabular}


One reason is that the logistics standards in most of the ASEAN countries are not comprehensive and it has not yet formed a complete system of logistics standard. The majority of national standards are more than $60 \%$. Among them, the Philippine's port logistics standards which in the use of international standards was to $78 \%$, Singapore reached $80 \%$.

Another reason is that the difference in national conditions. This article lists four aspects:

\section{A. Government efficiency}

Government efficiency is crucial to the level of logistics services and the customs departments have the functions of inspection, examination and approval, supervision and so on. The higher efficiency of customs improves the less time that the good stays and the higher speed that the logistics flows.

\section{B. Innovation ability}

Through establishing the innovative mechanisms and networks, and actively using the knowledge and scientific and technological strength, constructing modern logistics services information, to realize the automated electronic data exchange, thereby improve the level of logistics services.

\section{Excellent human resources}

With a professional customs inspection team and a good logistics service labor force, the working efficiency of the country is relatively high which can save cost and the logistics reaches relatively a high level.

\section{Bank loans}

A country's infrastructure level reflects the level of logistics services, the more that infrastructure is complete, the faster that the speed of the country's logistics. Thus reducing the time cost of logistics can improve the level of logistics.

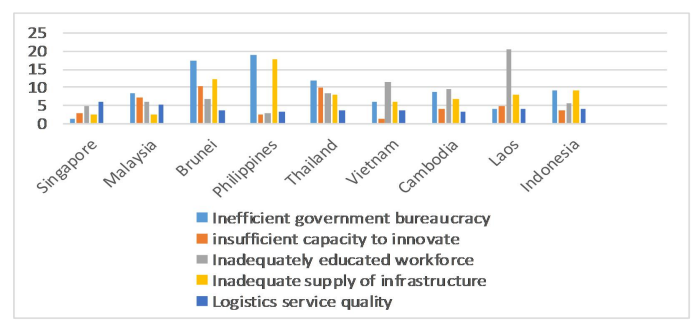

Fig. 1. Analysis of the state of the country

Data is compiled from the World Economic Forum, 20162017 Global Competitiveness Report (except Myanmar data).

Through analysis table analysis can be obtained: Singapore has automated the operation process and created a computer technology platform, including Trade Net, Port Net, Jurong Port Online, Marinet, Cargo Community Network. To complete the government departments of online information exchange, a substantial reduction in the number of customs clearance documents, saves time. As a developed country Singapore also has a higher Infrastructure level, excellent human resources and government efficiency. However, other countries have their own weaknesses. For example Thailand and Myanmar it takes five to seven days to clear the goods after the goods arrive at the port in Thailand. In Myanmar, it requires at least three weeks obtaining an export/import license and other documentation for each shipment; these are related to government inefficiencies. In Indonesia and Cambodia, lacking Excellent human resources there is language problem, as codes are in English and customs official do not fully understanding English. Through the above analysis, the level of logistics service is affected by the government efficiency, innovation ability, excellent human resources, infrastructure level and other factors, the higher the overall factor level, the higher the level of logistics services.

By rearranging Sumeet and Mark, (2011) Semi-structured questionnaire, collecting national logistics service policy related aspects of the study, and analyzing China and other international trade process problems, developing an inventory of barriers and related advice to free trade in the logistics services sector.

\section{China's Logistics Services Problem EnCOUntered IN THE PROCESS OF TRADE WITH ASEAN MEMBER COUNTRIES.}

\section{A. The technical level leads to time-consuming documentation requirements}

LSPs are required to submit the import/export documentation at the customs border of the respective country. The inefficiency in documentation arises due to the lack of full automation electronic data interchange (EDI) which results in a large number of documents that are required to be completed the lack of standard documentation form among countries and the lack of transparent regulations. Therefore, documentation consumes a large amount "dwell time". For example, the customs authorities of Indonesia require a number of different documents; albeit they often are the import licenses for any goods as well as the shipping list which are required by repetitive customs.

\section{B. The difference of logistics standards leads to strict inspection requirements}

Burdensome inspection requirements. WTO standards require that approximately 1 per cent of goods to be inspected during shipment. When there is a probability of smuggling or that the goods being shipped are of high value, customs of facials conduct a thorough inspection of the goods. But there is no clear range of goods to be examined. For instance, In Myanmar, all imports/exports have to be inspected. In most cases, manual inspection for exports takes about one working day. For import goods, it takes two to three days for inspection.

\section{The lack of standardized customs inspection personnel and logistics inspection standards}

As the taxes is different; shippers tend to arbitrarily classify their goods so as to pay minimum tax. For example, some customs classify toys as plastic goods while others classify them as decoration items. This misclassification will keep the goods detained at the port. So, the logistics costs also increase because of detention. For example, In Brunei, 
customs officials are not well educated in the classification system. So, the shippers have to rely on whatever they say. In Brunei and Thailand, customs official can change the classification codes arbitrarily and intentionally.

\section{Lacking cross-border coordination, except for the Philippines}

Where there is no adjoining border with other ASEAN countries, border coordination problem is present in almost all ASEAN countries. China will inevitably involve the problem of cross-border logistics in the process of land transport.

The customs of each country do not coordinate with each other, thus sometimes requiring duplication of documents at the border. In the process of trade between China and Thailand most of the goods passed through Laos. To truck to the Laos border, LSPs will need to meet multi-country requirements. In such a situation, two sets of documents for Thai and Laos customs will be required.

\section{E. Volatility in border traffic: Congestion is a problem at border checkpoints.}

Even in the efficient process of Singapore, there are 1-2 hours of traffic jam at the checkpoint. The same could be the case in Thailand.

\section{For Logistics SERVICES, We PUT ForWARD SOME SUGGESTIONS}

\section{A. Improving the efficiency of Customs approval}

China should promote the ASEAN Member States to take various measures to avoid obstruction of government administrative procedures on logistics services. Establish a one-stop service network to simplified procedures and provide convenience.

\section{B. Establishing a constructive stakeholder relationship}

China should establish a joint participation mechanism with ASEAN countries, so that all the stakeholders will have the opportunity to participate in the evaluation of the existing published regulations.

\section{Using new technology to improve logistics service environment}

More advanced technology and knowledge training should be given to more member countries to help countries accelerate the building of a modern, information-based logistics approval system. Promote the development of transportation, communications and other infrastructure projects as a priority and realize the interconnection of infrastructure in the ASEAN Free Trade area.

\section{Strengthen the coordination of relevant policies and regulations}

Technical standards, etc.. for example, a perfect commodity classification standard.

\section{CONCLUSIONS}

Through data analysis, the adoption of international standard and national conditions will affect the logistics service. In the process of trade between China and ASEAN member countries, analyze the government's efficiency, innovation, excellent human resources and infrastructure and so on, so as to know about the logistics level of the relevant countries. China should take measures to strengthen logistics service cooperation with ASEAN countries. As noted by Xuan $\mathrm{Li},(2016)$ include: improve the efficiency of Customs approval, establish a constructive stakeholder relationship, use new technology to improve logistics service environment, Strengthen the coordination of relevant policies and regulations, technical standards, Strengthen cooperation to deal with investment protectionism, establish an effective dispute settlement mechanism, etc.. Because the national policies and regulations have been improved, the international standard adoption rate is also improved, enterprises should fully understand the latest information of logistics services, this paper analyzes the influencing factors of logistics, hopes to help the logistics of enterprises, but also hope that the latter part of the logistics services to update and supplement.

\section{ACKNOWLEDGMENT}

Thanks for my postgraduate tutor and members of the anonymous reviewers for helpful comments and suggestions. Thanks Friends and family for their support.

\section{REFERENCES}

[1] APEC Policy Support Unit, IFAP Implementation in Facilitating Investment for The Asia Pacific Region, 2016.

[2] ASEANS Secretariat, ASEAN Investment Report 2015-2016, vol. 10 2016

[3] B. Shepherd, and J.S. Wilson, "Trade facilitation in ASEAN member countries: Measuring progress and assessing priorities," Journal of Asian Economics 20, 2009, pp. 367-383.

[4] R.K. Jittichai, S. Wiracha, and S. Sumalee, "Evaluation of International Ports in Thailand through Trade Facilitation Indices Freight Foewarders," Procedia-Social and Behavioral Sciences, vol. 111, 2014, pp. 1073-1082.

[5] X. Li, "The Progress, Evaluation, and Cooperation of the Investmen Facilitation between China and ASEAN," Journal of AROUND SOUTHEA STASIA, 2016

[6] P.B. Turnes, and E. Ricardo, "A framework for transparency in international trade," Investigaciones Europeas de Direccióny Economía de la Empresa,vol. 21, 2015, pp. 1-8.

[7] G. Sumeet, G.Mark, D. Robert, and M. Garg, "Assessing trade friendliness of logistics services in ASEAN," Asia Pacific Journal of Marketing and Logistics, vol. 23, pp. 773-792. 